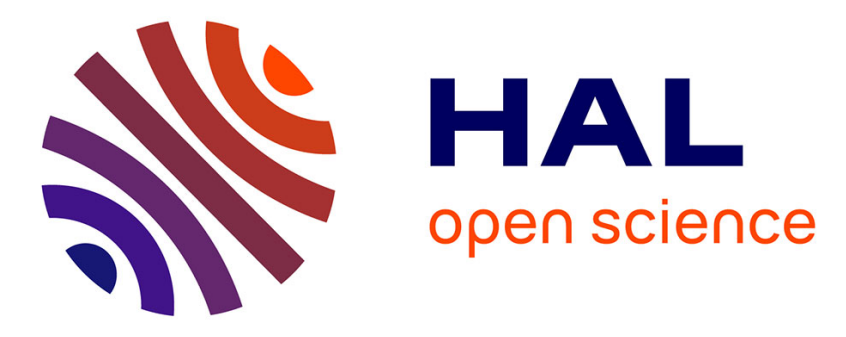

\title{
New insights into cerium anomalies in organic-rich alkaline waters
}

Olivier Pourret, Mélanie Davranche, Gérard Gruau, Aline Dia

\section{To cite this version:}

Olivier Pourret, Mélanie Davranche, Gérard Gruau, Aline Dia. New insights into cerium anomalies in organic-rich alkaline waters. Chemical Geology, 2008, 251 (1-4), pp.120-127. 10.1016/j.chemgeo.2008.03.002 . insu-00300489

\section{HAL Id: insu-00300489 \\ https://hal-insu.archives-ouvertes.fr/insu-00300489}

Submitted on 6 Nov 2009

HAL is a multi-disciplinary open access archive for the deposit and dissemination of scientific research documents, whether they are published or not. The documents may come from teaching and research institutions in France or abroad, or from public or private research centers.
L'archive ouverte pluridisciplinaire HAL, est destinée au dépôt et à la diffusion de documents scientifiques de niveau recherche, publiés ou non, émanant des établissements d'enseignement et de recherche français ou étrangers, des laboratoires publics ou privés. 


\section{NEW INSIGHTS INTO CERIUM ANOMALIES IN \\ ORGANIC RICH ALKALINE WATERS}

Olivier Pourret $^{1,2, *}$, Mélanie Davranche ${ }^{1}$, Gérard Gruau ${ }^{1}$, Aline Dia ${ }^{1}$

${ }^{1}$ Géosciences Rennes - Université Rennes 1 - CNRS, Campus de Beaulieu, 35042 Rennes Cedex, France

${ }^{2}$ Département Géosciences - Institut Polytechnique LaSalle Beauvais, 19 rue Pierre Waguet, 60026 Beauvais Cedex, France

*Corresponding author: tel.: 333440689 79; fax: 333440689 70; e-mail address: olivier.pourret@1asallebeauvais.fr. 
Abstract - Cerium anomaly development in natural waters is commonly related to the mechanism of oxidative scavenging of tetravalent cerium by iron and/or manganese oxides. In this study, a new mechanism for the development of Ce anomalies is described, which combines the oxidation of $\mathrm{Ce}$ at high $\mathrm{pH}$ by carbonate and the preferential adsorption of $\mathrm{Ce}(\mathrm{IV})$ to humic acids. This new mechanism was experimentally elucidated by studying the competition between carbonate and humic acids for complexing rare earth elements (REE). These experiments showed that above $\mathrm{pH} 8.2,8.6$ or 8.7 (with decreasing alkalinity from $10^{-2}$ to $10^{-3} \mathrm{~mol} \mathrm{~L} \mathrm{~L}^{-1}$ ), $\mathrm{Ce}$ (III) is readily oxidized into $\mathrm{Ce}(\mathrm{IV})$, which is then preferentially adsorbed onto humic acids. This preferential uptake of Ce results in the development of a negative Ce anomaly (as low as 0.05) in the "truly" dissolved part of the solution (i.e., $<5 \mathrm{kDa}$ ), and a complementary positive anomaly (up to 1.22) occurs in the organic colloidal fraction. The positive and negative Ce anomalies remained hidden until the organic and inorganic fractions of the solution were separated. Therefore, Ce anomalies became apparent only after ultrafiltration of the waters and the subsequent isolation of the two fractions. The Ce anomaly is thus more likely to be a proxy of redox conditions in ultrafiltered waters than in unfiltered waters or in waters filtered to $<0.2 \mu \mathrm{m}$. The removal (e.g., by coagulation and/or flocculation) of organic molecules in organic-rich alkaline waters might lead to the development of a negative Ce anomaly in the resulting organicpoor waters. In contrast, some organic-poor alkaline waters may develop positive Ce anomalies due to preferential complexation of $\mathrm{Ce}(\mathrm{IV})$ by dissolved carbonate.

Keywords: Rare earth elements, humic acid, carbonate, ultrafiltration, cerium anomaly 


\section{Introduction}

Rare earth elements (REE) exhibit a trivalent (+III) oxidation state in natural waters. However, among the REE, only Ce can readily be oxidized to the (+IV) state. Negative cerium anomalies have been extensively observed in seawater (e.g., Elderfield and Greaves, 1982; De Baar et al., 1985; Elderfield, 1988; German et al., 1991; German et al., 1995), river waters and groundwaters (e.g., Smedley, 1991; Braun et al., 1998; Dia et al., 2000; Leybourne et al., 2000). Seawater, for example, shows a strong negative Ce anomaly mirrored by a positive anomaly in hydrogenic ferromanganese nodules (Piper, 1974; Elderfield et al., 1981; De Carlo and McMurtry, 1992). However, the mechanism whereby Ce is fractionated from its trivalent neighbors in aquatic environments remains somewhat controversial.

Moffett $(1990,1994)$ demonstrated that Ce can be oxidized by bacteria. Ce oxidation can also occur abiotically through oxidation/scavenging of dissolved $\mathrm{Ce}$ (III) by $\mathrm{Mn}$ and $\mathrm{Fe}$ oxyhydroxides (Koeppenkastrop and De Carlo, 1992; De Carlo et al., 1998; Bau, 1999; Ohta and Kawabe, 2001). Because $\mathrm{Ce}(\mathrm{IV})$ is more strongly adsorbed than the trivalent REE, the Ce oxidation/scavenging reaction may result in solutions displaying a negative Ce anomaly, whereas solids exhibit positive Ce anomalies (e.g., De Baar et al., 1988). Negative Ce anomalies are widespread in both oceanic and fresh waters (De Baar et al., 1985; Elderfield, 1988; Sholkovitz, 1995; Byrne and Sholkovitz, 1996). In contrast, positive Ce anomalies in REE patterns have only been reported in alkaline lake waters (Möller and Bau, 1993; Johannesson and Lyons, 1994; Johannesson et al., 1994). Such positive Ce anomalies were interpreted as resulting from the stabilization of carbonato-Ce(IV)-complexes in solution leading to enhanced abundances of Ce(IV) in comparison with its trivalent REE neighbors (Möller and Bau, 1993). Positive Ce anomalies may be more common features of alkaline, carbonate-rich and aerobic waters than previously recognized, but further studies need to be done to generalize this feature. 
However, recent studies (Davranche et al., 2004; 2005) experimentally demonstrated that the complexation of REE by dissolved humic substances prevents any Ce anomaly development during REE partitioning between Fe- and Mn- oxyhydroxides and solution. Besides these studies (e.g., Davranche et al., 2004; 2005) and those of Tipping (1993) and Tang and Johannesson (2003) who show modelling results that extend to $\mathrm{pH}>9$, no experiments have been so far conducted regarding the case of organic-rich, alkaline waters.

Competition between carbonate and organic matter with respect to REE speciation in fresh waters raises several questions such as: (i) Considering that Ce oxidation can occur by carbonate-mediated complexation (Möller and Bau, 1993) and by analogy with the mechanisms described in the combined presence of Fe and Mn oxyhydroxide and organic matter, what will be the impact of organic matter on Ce anomaly development in a carbonate-rich system? Organic matter is both a REE competitor with respect to carbonate, and a scavenging surface likely to adsorb Ce(IV); will the dominant mechanism be the complexation of Ce(IV) with carbonate or its adsorption by organic matter? (iii) Is REE fractionation between both phases balanced? (iv) What will be the impact of organic matter on the magnitude of the Ce anomaly? In order to assess the role of humic acid and carbonate competition on Ce anomaly development in waters, batch equilibration experiments with REE, Aldrich HA and carbonate were performed for the 14 naturally occurring REE simultaneously at alkaline $\mathrm{pH}$ (from 6.0 to 11.0 ).

\section{Materials and methods}

All chemicals used were of analytical grade, and all the experimental solutions were prepared with doubly deionized water (MilliQ system, Millipore ${ }^{\mathrm{TM}}$ ). Complexes were prepared in polyethylene containers previously soaked in $10 \%$ Ultrapure $\mathrm{HNO}_{3}$ for $48 \mathrm{~h}$ at $60{ }^{\circ} \mathrm{C}$, then rinsed with MilliQ water for $24 \mathrm{~h}$ at $60{ }^{\circ} \mathrm{C}$ to remove all possible REE contamination sources. Synthetic 
REE solutions were prepared from nitrate REE standards $\left(10 \mathrm{mg} \mathrm{L}^{-1}\right.$, Accu Trace ${ }^{\mathrm{TM}}$ Reference Standard). All experiments were carried out at room temperature (i.e., $20^{\circ} \mathrm{C} \pm 2$ ).

\subsection{Humic acid}

Purified humate, referred to as HA (humic acid), was obtained from synthetic Aldrich ${ }^{\mathrm{TM}}$ humic acid (Aldrich ${ }^{\mathrm{TM}}$, H1, 675-2) following the protocol described by Vermeer et al. (1998). The HA sample was freeze-dried and stored in a glass container at room temperature. HA obtained was ash free and in its protonated form, with the following elemental composition (in weight percent): $\mathrm{C}=55.8 \%, \mathrm{O}=38.9 \%, \mathrm{H}=4.6 \%, \mathrm{~N}=0.6 \%$ and has a mean molecular weight of $23 \mathrm{kDa}$ (Vermeer et al., 1998). Concentrations of REE in the HA were below the detection limit of ICP-MS measurement (i.e., below $1 \mathrm{ng} \mathrm{L}^{-1}$ ). Prior to use, the freeze-dried humate was resuspended overnight in an $0.001 \mathrm{~mol} \mathrm{~L}^{-1} \mathrm{NaCl}$ electrolyte solution at $\mathrm{pH}=10.0$, to ensure complete dissolution of humate (Davranche et al., 2004; 2005).

\subsection{Experimental set-up and analytical procedure descriptions}

The role of HA competing with carbonate on Ce anomaly development in alkaline-rich waters was investigated using a standard batch equilibration technique. $100 \mathrm{~mL}$ of solution were prepared with $50 \mu \mathrm{g} \mathrm{L}^{-1}$ of each REE (e.g., $360 \mathrm{nmol} \mathrm{L}{ }^{-1}$ La to $286 \mathrm{nmol} \mathrm{L}{ }^{-1} \mathrm{Lu}$ ), $5 \mathrm{mg} \mathrm{L}^{-1}$ of HA and various concentrations of $\mathrm{NaHCO}_{3}$ (from $10^{-3}$ to $10^{-2} \mathrm{~mol} \mathrm{~L}^{-1}$ ) in a $10^{-3} \mathrm{~mol} \mathrm{~L}^{-1} \mathrm{NaCl}-$ solution. Prior to addition of $\mathrm{NaHCO}_{3}$, the $\mathrm{pH}$ of the solution was 4.0. The initial hydroxide concentration was thus low (ca. $10^{-10} \mathrm{~mol} \mathrm{~L}^{-1}$ ), leading to negligible concentration of $\mathrm{LnOH}^{2+}$. After addition of $\mathrm{NaHCO}_{3}$, the $\mathrm{pH}$ increased to 5.0 and was then adjusted to the needed $\mathrm{pH}$ in the range of 6.6 to 10.6 by adding $\mathrm{NaOH}$ (diluted from a stock at $4 \mathrm{~mol} \mathrm{~L}^{-1}$ ). Under these experimental conditions, inorganic speciation calculations have shown that hydroxide and free 
species are only present at low concentrations (i.e., $<0.2 \%$ and $<3.8 \%$ of the inorganic fraction for $\mathrm{La}$ after the addition of $\mathrm{NaOH}$ to bring the $\mathrm{pH}$ to the range of 6.6 to 10.6, respectively; Pourret et al., 2007a). The pH was measured with a combined Radiometer Red Rod electrode. The electrode was calibrated with standard solutions (WTW'M $\mathrm{pH} 4.0,7.0$ and 10.0). The accuracy of the $\mathrm{pH}$ measurement was $\pm 0.05 \mathrm{pH}$ units. The redox potential was measured with a Mettler combinated Pt electrode (Eh varies between 350 and $450 \mathrm{mV}$ ). Ionic strength was thus different between samples, varying from $1.33 \times 10^{-3} \mathrm{~mol} \mathrm{~L}^{-1}$ to $2.58 \times 10^{-3} \mathrm{~mol} \mathrm{~L}^{-1}, 2.88 \times 10^{-3}$ mol L $\mathrm{L}^{-1}$ to $8.83 \times 10^{-3} \mathrm{~mol} \mathrm{~L}^{-1}$ and $5.15 \times 10^{-3} \mathrm{~mol} \mathrm{~L}^{-1}$ to $1.62 \times 10^{-2} \mathrm{~mol} \mathrm{~L}^{-1}$, respectively for the three increasing alkalinity conditions (i.e., $10^{-3} \mathrm{~mol} \mathrm{~L}^{-1}, 5 \times 10^{-3} \mathrm{~mol} \mathrm{~L}^{-1}$ and $10^{-2} \mathrm{~mol} \mathrm{~L}^{-1}$ ).

Experimental solutions were stirred for $48 \mathrm{~h}$ (equilibrium time determined from preliminary kinetic experiments) to allow equilibration and partitioning of REE between the aqueous solution and the humate suspension. Aliquots of $10 \mathrm{~mL}$ were sampled twice: (i) at the beginning of the experiment; and (ii) after $48 \mathrm{~h}$, at equilibrium state. REE complexed by the HA were separated from the remaining inorganic REE by ultrafiltration. Ultrafiltrations were carried out by centrifugating the $10 \mathrm{~mL}$ solution samples through $15 \mathrm{~mL}$ centrifugal tubes equipped with permeable membranes of $5 \mathrm{kDa}$ pore size (Millipore Amicon Ultra-15). All centrifugal filtering devices used were washed and rinsed with $0.1 \mathrm{~mol} \mathrm{~L}^{-1} \mathrm{HCl}$ and MilliQ water twice before use in order to minimize contamination. Centrifugations were performed using a Jouan G4.12 centrifuge with swinging bucket rotor at $3000 \mathrm{~g}$ for 30 minutes. This allowed the REE-HA complexes to be quantitatively separated from inorganic REE species, notably the carbonate complexes. The selectivity of the $5 \mathrm{kDa}$ membrane with respect to the REE-HA complexes was verified by monitoring the Dissolved Organic Carbon (DOC) contents of the ultrafiltrates. Results showed that the latter were systematically lower or equal to blank values (below $0.1 \mathrm{mg}$ $\mathrm{L}^{-1}$ ). Possible adsorption of inorganic REE species onto ultrafiltration membranes or onto cell walls was also monitored. The lack of REE adsorption onto the ultrafiltration membranes or the walls of the cell devices used was checked in two ways. First, inorganic REE solutions of given 
REE concentration were ultrafiltered several times. Results showed that between $98.91 \%$ (for $\mathrm{Ho}$ ) and $99.98 \%$ (for $\mathrm{Yb}$ ) of the REE present in solution was recovered in the ultrafiltrates, demonstrating that none of the REE was adsorbed either, on the membrane or, on the walls of the cell devices. Secondly, in order to check that no retention of REE or carbonate occurs inside the membrane during ultrafiltration, mass balance calculations were performed. The initial concentration of each element was compared with the sum of each element concentration in the ultrafiltrate and the retentate. The element concentration sum measured from the ultrafiltrate and the retentate differed from the initial content by less than $2 \%$ for REE and by less than $5 \%$ for dissolved carbonate and DOC. Moreover, in order to ensure that no precipitation occurred (e.g., as cerianite), samples were filtered through $0.2 \mu \mathrm{m}$ cellulose acetate membranes (Sartorius) before ultrafiltration. No difference was found (within the uncertainty of the measurements) between the $0.2 \mu \mathrm{m}$ filtrate and the raw sample for REE, HA and carbonate.

The amount of REE complexed with HA corresponds to the difference between the initial REE concentration and the remaining REE concentration into the $<5 \mathrm{kDa}$ ultrafiltrates. $\mathrm{REE}$ concentrations were determined at Rennes University using an Agilent Technologies ${ }^{\mathrm{TM}} \mathrm{HP} 4500$ ICP-MS instrument. Quantitative analyses were performed using a conventional external calibration procedure. Three external standard solutions with REE concentrations similar to the analyzed samples were prepared from a multi-REE standard solution (Accu Trace ${ }^{\mathrm{TM}}$ Reference, $10 \mathrm{mg} \mathrm{L}^{-1}$, USA). Indium was added to all samples as an internal standard at a concentration of $0.87 \mu \mathrm{mol} \mathrm{L} \mathrm{L}^{-1}\left(100 \mu \mathrm{g} \mathrm{L}^{-1}\right)$ to correct for instrumental drift and possible matrix effects. Indium was also added to the external standard solutions. Calibration curves were calculated from measured REE/indium intensity ratios. The instrumental error on REE analysis in our laboratory as established from repeated analyses of multi-REE standard solution (Accu Trace ${ }^{\mathrm{TM}}$ Reference, USA) and of the SLRS-4 water standard is below $\pm 2 \%$ (Dia et al., 2000; Davranche et al., 2005). Chemical blanks of individual REE were all lower than the detection limit $\left(1 \mathrm{ng} \mathrm{L}{ }^{-1}\right)$, which is negligible since they are three to four orders of magnitude lower than the concentrations 
measured in the synthetic solutions used for the complexation experiments. Organic sample aliquots were all immediately digested with sub-boiled nitric acid $\left(\mathrm{HNO}_{3} 14 \mathrm{~mol} \mathrm{~L}{ }^{-1}\right)$ at $100^{\circ} \mathrm{C}$ and then resolubilized in $0.4 \mathrm{~mol} \mathrm{~L}^{-1} \mathrm{HNO}_{3}$ after complete evaporation in order to avoid any matrix effect due to organic matter during mass analysis. DOC concentrations were determined at Rennes University using a Shimadzu 5000 TOC analyzer. The accuracy of DOC concentration measurements is estimated at $\pm 5 \%$ as determined by repeated analyses of freshly prepared standard solutions (potassium biphtalate). Carbonate concentrations were determined by potentiometric titrations $\left(\mathrm{HCl} 0.1 \mathrm{~mol} \mathrm{~L}^{-1}\right)$, with Gran method analysis. The uncertainty was better than $5 \%$.

\section{Experimental results}

The role of HA and carbonate competition on Ce oxidation and Ce anomaly development is examined by considering the REE patterns of the organic and inorganic fractions as a function of $\mathrm{pH}$. As shown in a companion paper (Pourret et al., 2007a) inorganic REE speciation can be modelled using WHAM 6 (Tipping, 1998) in which well accepted infinite dilution $\left(25^{\circ} \mathrm{C}\right)$ stability constants for REE carbonate complexes are included (Luo and Byrne, 2004). REE were shown to be mostly carried as carbonate complexes. REE carbonate complexation is described by the following equations:

$$
\begin{aligned}
& \mathrm{Ln}^{3+}+\mathrm{CO}_{3}{ }^{2-} \leftrightharpoons \mathrm{LnCO}_{3}{ }^{+} \\
& \mathrm{Ln}^{3+}+2 \mathrm{CO}_{3}{ }^{2-} \leftrightharpoons \mathrm{Ln}\left(\mathrm{CO}_{3}\right)_{2}{ }^{-}
\end{aligned}
$$


whereas humic complexation is described by the following equation:

$$
\mathrm{Ln}^{3+}+\mathrm{HA}^{-} \leftrightharpoons \mathrm{LnHA}^{2+}
$$

As shown by several studies (e.g., Luo and Byrne, 2004), $\mathrm{LnCO}_{3}{ }^{+}$and $\mathrm{Ln}\left(\mathrm{CO}_{3}\right)_{2}{ }^{-}$ concentrations strongly depend on $\mathrm{pH}$ and carbonate content. $\mathrm{LnCO}_{3}{ }^{+}$concentrations decrease with $\mathrm{pH}$ increase above ca. 7 , whereas $\mathrm{Ln}\left(\mathrm{CO}_{3}\right)_{2}{ }^{-}$concentrations increase with increasing $\mathrm{pH}$. $\mathrm{Ln}\left(\mathrm{CO}_{3}\right)_{2}{ }^{-}$and $\mathrm{LnCO}_{3}{ }^{+}$concentrations thus increase with carbonate alkalinity (Fig. 1). Moreover, no ternary surface complex between metal $\left(\mathrm{Ln}^{3+}\right)$, ligand $\left(\mathrm{CO}_{3}{ }^{2-}\right)$ and surface (HA) was considered (Pourret et al., 2007a).

Negative Ce anomalies are clearly developed at high $\mathrm{pH}$ in the ultrafiltrates, which is mirrored by a positive Ce anomaly in the HA colloids fraction (Fig. 1). The progressive development of a Ce anomaly is accompanied by increased fractionation of the REE patterns. Ultrafiltrates become progressively enriched in heavy REE (HREE) with increasing $\mathrm{pH}$ and alkalinity, whereas the fraction corresponding to HA complexes show progressive LREE enrichment. The progressive LREE enrichment in the HA fraction and thus the corresponding progressive HREE enrichment in the ultrafiltrates correspond to the competitive reaction between mono- (Eq. [1]) and di- (Eq. [2]) carbonato-complexation reactions. This result is consistent with the difference in the complexation constants of LREE- and HREE-carbonate complexes (Luo and Byrne, 2004). The influence of redox processes on Ce/REE fractionation can be evaluated by calculating the magnitude of Ce anomalies as follows:

$$
C e / C e^{*}=\frac{C e}{\operatorname{Pr}+(\operatorname{Pr}-N d)}
$$


Equation 4 was selected to avoid any La anomaly interference during $\mathrm{Ce} / \mathrm{Ce}$ * calculation. In our study, relative values of $\mathrm{Ce}, \mathrm{Pr}$ and $\mathrm{Nd}$ are used rather than normalized $\mathrm{Ce}$, $\mathrm{Pr}$ and $\mathrm{Nd}$ values, because in our experimental study we can normalize to initial concentrations. Ce anomaly values greater than or less than one represent preferential enrichment or removal of Ce, respectively. The development of a negative $\mathrm{Ce}$ anomaly is observed for $\mathrm{pH}$ values greater than 8.2, 8.6 and 8.7, depending on alkalinity values (Fig. 2). The magnitude of the negative Ce anomaly in solution increases with $\mathrm{pH}$ from 1.00 to 0.05 (Fig. 2a). The development of a negative Ce anomaly in solution is observed for various carbonate concentrations. Negative Ce anomalies develop for $\mathrm{CO}_{3}^{2-}$ concentrations above $10^{-4} \mathrm{~mol} \mathrm{~L}^{-1}$ (Fig. 2b). Moreover, the development of the negative Ce anomaly is not related to ionic strength (Fig. 2c); Ce anomaly increases whereas ionic strength remains in the same order of magnitude (i.e., between $1.33 \times 10^{-}$

${ }^{3} \mathrm{~mol} \mathrm{~L}^{-1}$ and $2.58 \times 10^{-3} \mathrm{~mol} \mathrm{~L}^{-1}, 2.88 \times 10^{-3} \mathrm{~mol} \mathrm{~L}^{-1}$ and $8.83 \times 10^{-3} \mathrm{~mol} \mathrm{~L}^{-1}$ and $5.15 \times 10^{-3} \mathrm{~mol}$ $\mathrm{L}^{-1}$ and $1.62 \times 10^{-2} \mathrm{~mol} \mathrm{~L}^{-1}$, respectively for the three increasing alkalinity conditions). Complementary positive Ce anomalies develop in the HA fraction. However, positive Ce anomalies are only significant (up to 1.22) for the more competing condition (i.e., for alkalinity of $\left.10^{-2} \mathrm{~mol} \mathrm{~L}^{-1}\right)$

\section{Discussion}

\subsection{Mechanism of cerium anomaly development}

This study demonstrates the development of a negative cerium anomaly in the inorganic fraction of a carbonate-HA suspension at alkaline $\mathrm{pH}$ and high $\left[\mathrm{CO}_{3}{ }^{2-}\right]$, whereas the development of a positive cerium anomaly is observed in the humic phase. Oxidation of $\mathrm{Ce}$ (III) to $\mathrm{Ce}$ (IV) leads to the development of cerium anomalies compared with the adjacent REE, which are strictly trivalent. The oxidation of $\mathrm{Ce}(\mathrm{III})$ to $\mathrm{Ce}(\mathrm{IV})$ cannot solely occur in oxic waters (i.e., 
without any complexing ligand) as the $\mathrm{pe}^{0}$ (corresponding to $0.059 \mathrm{E}^{0}$ at $25^{\circ} \mathrm{C}$ ) is outside the stability field of water and thus free Ce(IV) ion in solution should not exist (De Baar et al., 1988). In our experimental conditions, even if $\mathrm{Ce}(\mathrm{IV})$ could occured as cerianite (i.e., $\mathrm{CeO}_{2}$ ), no cerianite was precipitated. It is evidenced by similar patterns of the unfiltered and filtered $(0.2$ $\mu \mathrm{m})$ samples, considering that any precipitation should be removed from solution by filtration (e.g., Braun et al., 1990; 1998; Takahashi et al., 2000).

It is thus necessary to have another mechanism to oxidize Ce(III). As stated by Stumm and Morgan (1996) for $\mathrm{Fe}(\mathrm{III}) / \mathrm{Fe}(\mathrm{II})$ redox couple, at $\mathrm{pH}=7.0, \mathrm{pe}^{0}$ decreases in the presence of most complex formers, especially chelates with oxygen donor atoms, because these ligands form stronger complexes with Fe(III) than with Fe(II). Electron transfer can thus occur at pH 7.0 over the entire range of the stability of water. These principles are applicable to other redox system such as the $\mathrm{Ce}(\mathrm{III}) / \mathrm{Ce}(\mathrm{IV})$ redox couple. $\mathrm{Ce}(\mathrm{III})$ to $\mathrm{Ce}(\mathrm{IV})$ oxidation could thus occur in our experimental conditions.

Möller and Bau (1993), Johannesson and Lyons (1994) and Johannesson et al. (1994) have shown that REE patterns for alkaline, carbonate-rich, aerobic lake waters display HREE enrichment and, in some cases, positive Ce anomalies. Möller and Bau (1993) proposed that Ce anomalies result from the oxidation of trivalent $\mathrm{Ce}$ to tetravalent $\mathrm{Ce}$ by dissolved carbonate and stabilization of pentacarbonato-Ce(IV)-complexes in solution. Complexation by carbonate could thus induce the oxidation of trivalent Ce to tetravalent form as previously stated by Stumm and Morgan (1996) for Fe(III)/Fe(II) redox couple. Moreover, Doležal and Novák (1959), Möller and Bau (1993) and Riglet-Martial et al. (1998) have shown that strong carbonato-Ce-complexes may form following the half oxidation reaction:

$$
\mathrm{Ce}(\mathrm{III})\left(\mathrm{CO}_{3}\right)_{2}{ }^{-}+3 \mathrm{CO}_{3}{ }^{2-} \leftrightharpoons \mathrm{Ce}(\mathrm{IV})\left(\mathrm{CO}_{3}\right)_{5}{ }^{6-}+\mathrm{e}^{-}
$$


Considering the experimental conditions and solution composition during oxidation of $\mathrm{Ce}(\mathrm{III})$ to $\mathrm{Ce}(\mathrm{IV})$, the corresponding complementary half reduction reaction is probably the reduction of dissolved oxygen $\left(\mathrm{pe}^{0}=+20.75\right.$ for the redox couple $\left.\mathrm{O}_{2}(\mathrm{~g}) / \mathrm{H}_{2} \mathrm{O}\right)$.

$$
\mathrm{O}_{2}(\mathrm{~g})+4 \mathrm{H}^{+}+4 \mathrm{e}^{-} \leftrightharpoons 2 \mathrm{H}_{2} \mathrm{O}
$$

Combining Eq. [5] and Eq. [6] will result in:

$$
4 \mathrm{Ce}(\mathrm{III})\left(\mathrm{CO}_{3}\right)_{2}{ }^{-}+12 \mathrm{CO}_{3}{ }^{2-}+\mathrm{O}_{2}(\mathrm{~g})+4 \mathrm{H}^{+} \leftrightharpoons 4 \mathrm{Ce}(\mathrm{IV})\left(\mathrm{CO}_{3}\right)_{5}{ }^{6-}+2 \mathrm{H}_{2} \mathrm{O}
$$

Such a mechanism may be considered in our experiments as the free energy change is negative and thus indicates a spontaneous process. Indeed, the $\Delta \mathrm{G}^{0}$ of Eq. [7] has been evaluated using data from Riglet-Martial et al. (1998) to $-947.84 \mathrm{~kJ} \mathrm{~mol}^{-1}$ (i.e., using $\Delta \mathrm{G}_{\mathrm{f}}^{0}$ of $\mathrm{Ce}(\mathrm{III})\left(\mathrm{CO}_{3}\right)_{2}^{-}$ and $\mathrm{Ce}(\mathrm{IV})\left(\mathrm{CO}_{3}\right)_{5}{ }^{6-}$ extrapolated to $-1164.67 \mathrm{~kJ} \mathrm{~mol}^{-1}$ and $-2866.74 \mathrm{~kJ} \mathrm{~mol}^{-1}$, respectively). Although there are uncertainties as to what controls aqueous Ce chemistry what is relevant here is that oxidation of $\mathrm{Ce}(\mathrm{III})$ is sensitive to carbonate concentration and HA is not directly implied in the oxidation process. Indeed, REE-humic substances complexation experiments have not demonstrated the development of Ce anomalies (Sonke and Salters, 2006; Pourret et al., 2007b).

In order to check if such a mechanism (i.e., $\mathrm{Ce}(\mathrm{III})$ oxidation) could occur in the experimental conditions encountered in our study, two pe-pH diagrams for the system Ce-C-O-H (Fig. 3a and 3b) were built using this reaction for a range of ionic strength $(I)$ relevant to our experimental conditions (data compiled from Doležal and Novak, 1959; De Baar et al., 1988; Möller and Bau, 1993). Due to the presence of carbonate and HA complexes, no $\mathrm{Ce}(\mathrm{OH})_{3}$ develops. As carbonate and HA form stronger complexes with Ce compared to hydroxide, hydroxide species are only present at very low concentration in the $\mathrm{pH} 6.6-10.6$ range $(<0.2 \%$ as regards speciation calculations; Pourret et al., 2007a): this species is thus not considered in the 
diagram. As shown by Möller and Bau (1993), even if the exact value of the activity coefficient $\gamma$ of the pentacarbonato-Ce(IV)-complex remains unknown, a value of 6 was assumed and adopted for the $\log \mathrm{Q}$ equilibrium constant where $\mathrm{Q}=\gamma\left(\mathrm{Ce}(\mathrm{III})\left(\mathrm{CO}_{3}\right)_{2}{ }^{-}\right) / \gamma\left(\mathrm{Ce}(\mathrm{IV})\left(\mathrm{CO}_{3}\right)_{5}{ }^{6-}\right)$. The shift in $\mathrm{pH}$ from 8.0 to 9.0 within the pe range ca. 7.0 moves the $\mathrm{a}\left(\mathrm{Ce}(\mathrm{III})\left(\mathrm{CO}_{3}\right)_{2}{ }^{-}\right) / \mathrm{a}\left(\mathrm{Ce}(\mathrm{IV})\left(\mathrm{CO}_{3}\right)_{5}{ }^{6-}\right)$ equilibrium closer to $\mathrm{a}\left(\mathrm{Ce}(\mathrm{III})\left(\mathrm{CO}_{3}\right)_{2}^{-}\right) / \mathrm{a}\left(\mathrm{Ce}(\mathrm{IV}) \mathrm{O}_{2}\right)$ (with a defined as activity). The $\mathrm{a}\left(\mathrm{Ce}(\mathrm{III})\left(\mathrm{CO}_{3}\right)_{2}{ }^{-}\right) / \mathrm{a}\left(\mathrm{Ce}(\mathrm{IV})\left(\mathrm{CO}_{3}\right)_{5}{ }^{6-}\right)$ equilibrium is thus encountered before the a(Ce(III) $\left(\mathrm{CO}_{3}\right)_{2}{ }^{-}$ ) $/ \mathrm{a}\left(\mathrm{Ce}(\mathrm{IV}) \mathrm{O}_{2}\right)$ equilibrium. Therefore, $\mathrm{Ce}$ does not form $\mathrm{CeO}_{2}$ but $\mathrm{Ce}(\mathrm{IV})\left(\mathrm{CO}_{3}\right)_{5}{ }^{6-}$, under the conditions prevailing in the experiments (illustrated by black arrows on Fig. 3). Assuming that $\mathrm{a}\left(\mathrm{Ce}(\mathrm{III})\left(\mathrm{CO}_{3}\right)_{2}{ }^{-}\right) / \mathrm{a}\left(\mathrm{Ce}(\mathrm{IV})\left(\mathrm{CO}_{3}\right)_{5}{ }^{6-}\right) \quad$ is $\quad$ greater $\quad$ than $\mathrm{a}\left(\mathrm{Ce}(\mathrm{III})\left(\mathrm{CO}_{3}\right)_{2}{ }^{-}\right) / \mathrm{a}\left(\mathrm{Ce}(\mathrm{IV}) \mathrm{O}_{2}\right)$, $\mathrm{Ce}(\mathrm{IV})\left(\mathrm{CO}_{3}\right)_{5}{ }^{6-}$ will not be broken even if the $\mathrm{CeO}_{2}$ boundary is crosses with a further increase in $\mathrm{pH}$. Cerium oxidation following the above proposed mechanism is thus possible. As illustrated by Möller and Bau (1993), stabilization in solution of pentacarbonato-Ce(IV)-complex led to the development of a positive $\mathrm{Ce}$ anomaly in alkaline carbonate-rich solutions. However, in our experiment a negative $\mathrm{Ce}$ anomaly developed in solution, whereas a positive Ce anomaly developed in the organic humic fraction. To explain this we have to find a mechanism allowing such a phenomenon. The oxidation reaction needs then to be coupled with a preferential adsorption and removal from solution by a surface. In our study, the only complexing surfaces competing with carbonate are associated with HA. HA possess a range of weak acid groups including carboxylic sites. Nash and Sullivan (1991) presented complexation constants for Ce(IV)-carboxylate complexes that are ca. 2 time higher than Ce(III)-carboxylate complexes. It is thus possible that complexation of tetravalent species by HA will be higher than those of trivalent species. $\mathrm{Ce}(\mathrm{IV})$ can thus be preferentially adsorbed with respect to the other REE. Subsequently, we propose that Ce(IV) is preferentially adsorbed by humic substances following the reaction:

$$
\mathrm{Ce}(\mathrm{IV})\left(\mathrm{CO}_{3}\right)_{5}^{6-}+\mathrm{HA}^{-} \leftrightharpoons \mathrm{Ce}(\mathrm{IV}) \mathrm{HA}^{3+}+5 \mathrm{CO}_{3}{ }^{2-}
$$


$\mathrm{Ce}(\mathrm{IV})\left(\mathrm{CO}_{3}\right)_{5}{ }^{6-}$ could then be considered as a precursor complex for the tetravalent form of cerium adsorption to HA.

Complexation competition between $\mathrm{HA}$ and carbonate (i.e., $\mathrm{CO}_{3}{ }^{2-}$ ) for $\mathrm{REE}(\mathrm{III})$ results in a higher uptake of LREE by HA over HREE (Pourret et al., 2007a). Moreover, at high $\mathrm{CO}_{3}{ }^{2-}$ concentrations (i.e., $>10^{-3} \mathrm{~mol} \mathrm{~L}^{-1}$ ) and alkaline $\mathrm{pH}$ (i.e., $>8.0$ ) HA could preferentially adsorb Ce readily oxidized to $\mathrm{Ce}(\mathrm{IV})$ by carbonate. A positive Ce anomaly will thus develop on HA. This leads to the development of negatively Ce anomaly in the solution (Fig. 4). La and Ce behave similarly for $\mathrm{CO}_{3}{ }^{2-}$ concentrations below $10^{-3} \mathrm{~mol} \mathrm{~L}^{-1}$ and $\mathrm{pH}$ below 9.0. This corresponds to a classical competition reaction between two ligands: one inorganic (i.e., dissolved $\mathrm{CO}_{3}{ }^{2-}$ ) and one organic (i.e., HA). For more alkaline conditions (i.e., $\mathrm{CO}_{3}{ }^{2-}$ concentrations above $10^{-3}$ mol L ${ }^{-1}$ and $\mathrm{pH}$ above 9.0) $\mathrm{La}$ and $\mathrm{Ce}$ behave in different ways. $\mathrm{Ce}(\mathrm{III})$ is oxidized by carbonate to $\mathrm{Ce}(\mathrm{IV})$, which is then preferentially adsorbed by HA.

Comparison of Fig. $3 \mathrm{a}$ and $3 \mathrm{~b}$ allows us to illustrate the $\mathrm{pH}-$ and carbonate concentrationdependence of pentacarbonato-Ce(IV)-complex formation. As previously explained, $\mathrm{Ce}(\mathrm{IV})\left(\mathrm{CO}_{3}\right)_{5}{ }^{6-}$ can be formed only if $\mathrm{CeO}_{2}$ does not precipitate, that is, when the $\mathrm{a}\left(\mathrm{Ce}(\mathrm{III})\left(\mathrm{CO}_{3}\right)_{2}^{-}\right) / \mathrm{a}\left(\mathrm{Ce}(\mathrm{IV})\left(\mathrm{CO}_{3}\right)_{5}{ }^{6-}\right)$ ratio is higher than the $\mathrm{a}\left(\mathrm{Ce}(\mathrm{III})\left(\mathrm{CO}_{3}\right)_{2}{ }^{-}\right) / \mathrm{a}\left(\mathrm{Ce}(\mathrm{IV}) \mathrm{O}_{2}\right)$ ratio. Fig. $3 \mathrm{a}$ and $3 \mathrm{~b}$ provide evidence that the intercept of both equilibria moves towards more acidic $\mathrm{pH}$ when ionic strength, depending on alkalinity and consequently $\mathrm{CO}_{3}{ }^{2-}$ concentrations, increases. Moreover, when the HA/alkalinity ratio is high, only a small part of the REE is complexed by carbonate (i.e., $<1 \%$; Pourret et al., 2007a). This could be explained by the fact that the amount of HA necessary to break down the precursor complex is relatively small at circumneutral $\mathrm{pH}$ (i.e., 7). By contrast, when the HA/alkalinity ratio is low, the amount of precursor complex is higher and the amount of HA needed to break it down is larger. A higher $\mathrm{pH}$ is thus required to achieve these latter conditions. Indeed, as the electro-negativity of HA 
increases with $\mathrm{pH}$, at higher $\mathrm{pH}$ the amount of $\mathrm{HA}$ available to break down the precursor complex will thus be greater (e.g., Avena et al., 1999; Milne et al., 2001).

\subsection{Inferences on the understanding of $\mathrm{Ce}$ anomaly in natural waters}

Shallow organic-rich waters from several continental areas have been reported to display small negative Ce anomalies - or no anomaly at all - despite the occurrence of strongly oxidizing conditions (Viers et al., 1997; Braun et al., 1998; Dia et al., 2000; Gruau et al., 2004). In such organic-rich, acidic to circumneutral shallow groundwaters, the so-called "dissolved" REE pool generally occurs as REE(III)-humate complexes (Sholkovitz, 1995; Viers et al., 1997). Considering that Ce and REE occur predominantly as dissolved and colloidal organic complexes, Dia et al. (2000) put forward that either Ce precipitation and oxidation become impossible because of the complexation of $\mathrm{Ce}(\mathrm{III})$ by organic matter, to account for this lack of $\mathrm{Ce}$ anomalies. Experimental data reported by Davranche et al. $(2004 ; 2005)$ favour this hypothesis. In contrast, another hypothesis not previously considered is that the preferential Ce(IV) sorption is masked rather than inhibited as shown by the experimental results presented here. Our results show that an uptake of $\mathrm{Ce}(\mathrm{IV})$ species from the "truly" dissolved part of solution can occur producing negative cerium anomalies in the inorganic fraction in alkaline waters. However, as a complementary positive Ce anomaly develops on the HA, considering the whole REE pattern masks the preferential association of $\mathrm{Ce}(\mathrm{IV})$ with the colloidal fraction. Such a mechanism is observable in natural systems. Indeed, if we considered alkaline carbonate-rich waters from Lake Van (Möller and Bau, 1993), or from Abert Lake (i.e., alkalinity as high as 699 meq L ${ }^{-1}$; Johannesson et al., 1994) REE patterns display high positive Ce anomalies (i.e., from 1.88 to 3.85) interpreted as the result of oxidation of $\mathrm{Ce}(\mathrm{III})$ to $\mathrm{Ce}(\mathrm{IV})$ and subsequent stabilization of carbonato-Ce(IV)- complexes in the oxic, alkaline lake water (Möller and Bau, 1993; Johannesson et al., 1994). In contrast, if we consider waters like Mono Lake, alkaline carbonate 
rich waters (i.e., alkalinity between 625 and $719 \mathrm{meq} \mathrm{L}^{-1}$; Johannesson and Lyons, 1994) that have high DOC concentrations (i.e., between 78.9 and $89.4 \mathrm{mg} \mathrm{L}^{-1}$; Domagalski et al., 1989): these waters exhibited no or only slight positive Ce anomalies (i.e., from 0.98 to 1.37). Humic complexes may thus compete with carbonate for REE (e.g., Wood, 1992) and as previously shown by Dia et al. (2000) and Davranche et al. (2005; 2008) organic matter may inhibit Ce anomaly development. Moreover, the experimental conditions in this study are similar to seawater with respect to $\mathrm{pH}$, pe and alkalinity, although clearly different with respect to ionic strength. Some questions arise as regards Ce anomaly development in seawater especially since Hoyle et al. (1984) and Sholkovitz (1995) concluded that REE are strongly associated with organic matter and that removal of REE occurs due to flocculation of iron-organic matter colloids during estuarine mixing. As proposed by Lawrence and Kamber (2006) it is presently unclear if estuarine mixing implies a change in REE from organic to inorganic speciation and/or corresponding fractionation upon removal with iron oxyhydroxides. As shown in this study, in order to fully document Ce anomaly development, it is necessary to separate the colloidal phase from the dissolved phase.

As shown by Johannesson et al. (1994), speciation modelling is required to account for the speciation of REE in alkaline water. However, modelling such as that performed by Pourret et al. (2007a) does not take into account redox processes and thus does not consider Ce oxidation. Input of redox processes into models like WHAM 6.0 and Model VI (Tipping, 1998) is thus an important next step.

\section{Conclusions}

The role of HA competing with carbonate on Ce anomaly development in alkaline-rich waters was investigated using a standard batch equilibration technique. This experimental method combines an ultrafiltration technique and Inductively Coupled Plasma Mass Spectrometry. The 
role of $\mathrm{HA}$ and carbonate competition on $\mathrm{Ce}$ oxidation and $\mathrm{Ce}$ anomaly development was examined by considering the REE patterns of the organic and inorganic fractions as a function of $\mathrm{pH}$. A negative Ce anomaly is developed in the REE fraction bound to carbonate at $\mathrm{pH}$ above 8.2, 8.6 and 8.7 at alkalinities of $10^{-3} \mathrm{~mol} \mathrm{~L}^{-1}, 5 \times 10^{-3} \mathrm{~mol} \mathrm{~L}^{-1}$ and $10^{-2} \mathrm{~mol} \mathrm{~L}^{-1}$, respectively, whereas a positive $\mathrm{Ce}$ anomaly is developed in the organic fraction (i.e., $>5 \mathrm{kDa}$ ). Partitioning is observed between the organic phase (LnHA) and inorganic phases (Ln-carbonate). In the inorganic phase, REE patterns display HREE enrichment typical of seawater. These experiments shed more light, not only on a new way to develop a Ce anomaly, but also on the understanding of cerium anomaly cycle in natural waters at alkaline $\mathrm{pH}$. Indeed, these results suggest a new mechanism for cerium anomaly development. In the presence of carbonate, cerium is readily oxidized to Ce(IV), which is easily removed from solution by preferential adsorption to HA. Humic substances take up Ce(IV) from the "truly" dissolved part of solution (i.e., $<5 \mathrm{kDa}$ ), and a negative cerium anomaly thus develops in the inorganic fraction. A complementary positive Ce anomaly develops in the organic fraction. The preferential Ce(IV) sorption is masked. Therefore, Ce anomalies can not reliably be used as a proxy of redox conditions in unfiltered samples of organic-rich waters or in precipitates formed in equilibrium with organic-rich waters. Overall, the results of this study suggest that further considerations about organic matter should be taken into account especially at alkaline $\mathrm{pH}$ in organic-rich water by performing ultrafiltration on these samples. 


\section{Acknowledgements}

We thank the technical staff at Rennes (M. Le Coz-Bouhnik, O. Hénin and P. Petitjean) for their assistance during the experimental and analytical work. This research was supported by the CPER programs "Développement de la Recherche sur la Maîtrise de la Qualité de l'Eau en Bretagne" jointly funded by the French Government and the Council of Rennes Métropole. We thank Dr. M. Leybourne and Dr. M. Bau for their constructive comments that help to substantially improve the manuscript. 


\section{References}

Avena, M.J., Koopal, L.K. and van Riemsdijk, W.H., 1999. Proton binding to humate acids: electrostatic and intrinsic interactions. Journal of Colloid and Interface Science, 217: 3748.

Bau, M., 1999. Scavenging of dissolved yttrium and rare earths by precipitating iron oxyhydroxide: Experimental evidence for Ce oxidation, Y-Ho fractionation, and lanthanide tetrad effect. Geochimica et Cosmochimica Acta, 63: 67-77.

Braun, J.J., Pagel, M., Muller, J.P., Bilong, P., Michard, A. and Guillet, B., 1990. Cerium anomalies in lateritic profiles. Geochimica et Cosmochimica Acta, 54: 781-795.

Braun, J.J., Viers, J., Dupré, B., Polvé, M., Ndam, J. and Muller, J.P., 1998. Solid/liquid REE fractionation in the lateritic system of Goyoum, East Cameroon: the implication for the present dynamics of the soil covers of the humid tropical regions. Geochimica et Cosmochimica Acta, 62: 273-299.

Byrne, R.H. and Sholkovitz, E.R., 1996. Marine chemistry and geochemistry of the lanthanides. In K.A. Gschneidner Jr. and L.R. Eyring (Editors), Handbook on the Physics and Chemistry of Rare Earths, Vol. 23, Elsevier B.V., pp. 497-593.

Davranche, M., Pourret, O., Gruau, G. and Dia, A., 2004. Impact of humate complexation on the adsorption of REE onto Fe oxyhydroxide. Journal of Colloid and Interface Science, 277: 271-279.

Davranche, M., Pourret, O., Gruau, G., Dia, A. and Le Coz-Bouhnik, M., 2005. Adsorption of REE(III)-humate complexes onto $\mathrm{MnO}_{2}$ : Experimental evidence for cerium anomaly and lanthanide tetrad effect suppression. Geochimica et Cosmochimica Acta, 69: 4825-4835.

Davranche, M., Pourret, O., Gruau, G., Dia, A., Jin, D., and Gaertner, D., 2008. Competitive binding of REE to humic acid and manganese oxide: impact of reaction kinetics on development of Cerium anomaly and REE adsorption. Chemical Geology 247, 154-170. 
De Baar, H.J.W., Bacon, M.P., Brewer, P.G. and Bruland, K.W., 1985. Rare earth elements in the Pacific and Atlantic Oceans. Geochimica et Cosmochimica Acta, 49: 1943-1959.

De Baar, H.J.W., German, C.R., Elderfield, H. and van Gaans, P., 1988. Rare earth element distributions in anoxic waters of the Cariaco Trench. Geochimica et Cosmochimica Acta, 52: $1203-1219$.

De Carlo, E.H. and McMurtry, G.M., 1992. Rare-earth element geochemistry of ferromanganese crusts from the Hawaiian Archipelago, central Pacific. Chemical Geology, 95: 235-250.

De Carlo, E.H., Wen, X.-Y. and Irving, M., 1998. The influence of redox reactions on the uptake of dissolved Ce by suspended Fe and Mn oxide particles. Aquatic Geochemistry, 3: 357389.

Dia, A., Gruau, G., Olivié-Lauquet, G., Riou, C., Molénat, J. and Curmi, P., 2000. The distribution of rare earth elements in groundwaters: assessing the role of source-rock composition, redox changes and colloidal particle. Geochimica et Cosmochimica Acta, 64: 4131-4151.

Doležal, J. and Novák, J., 1959. Beitrag zum polarographischen Verhalten von drei- und vierwertigem Cer. Collection of Czechoslovak Chemical Communications, 24: 21822189.

Domagalski, J.L., Orem, W.H. and Eugster, H.P., 1989. Organic geochemistry and brine composition in Great Salt, Mono and Walker Lakes. Geochimica et Cosmochimica Acta, 53: $2857-2872$.

Elderfield, H., 1988. The oceanic chemistry of the rare earth elements in seawater. Philosophical Transaction Royal Society London, A325: 105-126.

Elderfield, H. and Greaves, M.J., 1982. The rare earth elements in seawater. Nature, 296: 214219. 
Elderfield, H., Hawkesworth, C.J., Greaves, M.J. and Calvert, S.E., 1981. Rare earth element geochemistry of oceanic ferromanganese nodules and associated sediments. Geochimica et Cosmochimica Acta, 45: 513-528.

German, C.R., Holiday, B.P. and Elderfield, H., 1991. Redox cycling of rare earth elements in the suboxic zone of the Black Sea. Geochimica et Cosmochimica Acta, 55: 3553-3558.

German, C.R., Masuzawa, T., Greaves, M.J., Elderfield, H. and Edmond, J.M., 1995. Dissolved rare earth elements in the Southern Ocean: Cerium oxidation and the influence of hydrography. Geochimica et Cosmochimica Acta, 59: 1551-1558.

Gruau, G., Dia, A., Olivié-Lauquet, G., Davranche, M. and Pinay, G., 2004. Controls on the distribution of rare earth elements in shallow groundwaters. Water Research, 38: 35763586 .

Hoyle, J., Elderfield, H., Gledhill, A., and Greaves, M., 1984. The behaviour of rare earth elements during mixing of river and sea waters. Geochimica et Cosmochimica Acta 48, 143-149.

Johannesson, K.H., Lyons, W.B. and Bird, D.A., 1994. Rare earth element concentrations and speciation in alkaline lakes from the western U.S.A. Geophysical Research Letters, 21: 773-774.

Johannesson, K.H. and Lyons, W.B., 1994. The rare earth element geochemistry of Mono Lake water and the importance of carbonate complexing. Limnology and Oceanography, 39: 1141-1154.

Koeppenkastrop, D. and De Carlo, E.H., 1992. Sorption of rare-earth elements from seawater onto synthetic mineral particles: An experimental approach. Chemical Geology, 95: 251263.

Lawrence, M. G. and Kamber, B. S., 2006. The behaviour of the rare earth elements during estuarine mixing - revisited. Marine Chemistry 100, 147-161. 
Leybourne, M.I., Goodfellow, W.D., Boyle, D.R. and Hall, G.M., 2000. Rapid development of negative Ce anomalies in surface waters and contrasting REE patterns in groundwaters associated with $\mathrm{Zn}-\mathrm{Pb}$ massive sulphide deposits. Applied Geochemistry, 15: 695-723.

Luo, Y.-R. and Byrne, R.H., 2004. Carbonate complexation of yttrium and the rare earth elements in natural rivers. Geochimica et Cosmochimica Acta, 68: 691-699.

Milne, C.J., Kinniburgh, D.G. and Tipping, E., 2001. Generic NICA-Donnan Model parameters for proton binding by humic substances. Environmental Science \& Technology, 35: 20492059.

Moffett, J.W., 1990. Microbially mediated cerium oxidation in sea water. Nature, 345: 421-423.

Moffett, J.W., 1994. A radiotracer study of cerium and manganese uptake onto suspended particle in Chesapeake Bay. Geochimica et Cosmochimica Acta, 58: 695-703.

Möller, P. and Bau, M., 1993. Rare-earth patterns with positive cerium anomaly in alkaline waters from Lake Van, Turkey. Earth and Planetary Sciences Letters, 117: 671-676.

Nash, K.L. and Sullivan, J.C., 1991. Kinetics of complexation and redox reactions of the lanthanides in aqueous solutions. In: K.A. Gschneidner Jr. and L.R. Eyring (Editors), Handbook on the Physics and Chemistry of Rare Earths. Elsevier Sciences B.V., pp. 347391.

Ohta, A. and Kawabe, I., 2001. REE(III) adsorption onto Mn dioxide and Fe oxyhydroxide: Ce(III) oxidation by Mn dioxide. Geochimica et Cosmochimica Acta, 65: 695-703.

Piper, D.Z., 1974. Rare earth elements in ferromanganese nodules and other marine phases. Geochimica et Cosmochimica Acta, 38: 1007-1022.

Pourret, O., Davranche, M., Gruau, G. and Dia, A., 2007a. Competition between humic acid and carbonates for rare earth elements complexation. Journal of Colloid and Interface Science, 305: 25-31.

Pourret, O., Davranche, M., Gruau, G. and Dia, A., 2007b. Rare Earth Elements complexation with humic acid. Chemical Geology, $243: 128-141$. 
Riglet-Martial, C., Vitorge, P. and Calmon, V., 1998. Electrochemical Characterisation of the Ce(IV) limiting carbonate complex. Radiochimica Acta, 82: 69-76.

Sholkovitz, E.R., 1995. The aquatic chemistry of rare earth elements in rivers and estuaries. Aquatic Geochemistry, 1: 1-34.

Smedley, P.L., 1991. The geochemistry of rare earth elements in groundwater from the Carnmenellis area, southwest England. Geochimica et Cosmochimica Acta, 55: 27672779 .

Sonke, J.E. and Salters, V.J.M., 2006. Lanthanide-humic substances complexation. I. Experimental evidence for a lanthanide contraction effect. Geochimica et Cosmochimica Acta, 70: 1495-1506.

Stumm, W. and Morgan, J.J., 1996. Aquatic Chemistry. Wiley Intersciences, New York.

Takahashi, Y., Shimizu, H., Usui, A., Kagi, H. and Nomura, M., 2000. Direct observation of tetravalent cerium in ferromanganese nodules and crusts by X-ray-absorption near-edge structure (XANES). Geochimica et Cosmochimica Acta, 64: 2929-2935.

Tang, J. and Johannesson, K.H., 2003. Speciation of rare earth elements in natural terrestrial waters: Assessing the role of dissolved organic matter from the modeling approach. Geochimica et Cosmochimica Acta, 67: 2321-2339.

Tipping, E., 1993. Modeling the competition between alkaline earth cations and trace metal species for binding by humic substances. Environmental Science \& Technology, 27: 520529.

Tipping, E., 1998. Humic Ion-Binding Model VI: an improved description of the interactions of protons and metal ions with humic substances. Aquatic Geochemistry, 4: 3-48.

Vermeer, A.W.P., Van Riemsdijk, W.H. and Koopal, L.K., 1998. Adsorption of humic acid to mineral particles. 1. Specific and electrostatic interactions. Langmuir, 14: 2810-2819.

Viers, J., Dupré, B., Polvé, M., Schott, J., Dandurand, J.-L. and Braun, J.J., 1997. Chemical weathering in the drainage basin of a tropical watershed (Nsimi-Zoetele site, Cameroon): 
comparison between organic-poor and organic-rich waters. Chemical Geology, 140: 181206. 


\section{Figures and appendix captions}

Fig. 1. Proportion of REE complexed to carbonates as a function of $\mathrm{pH}$ for various alkalinity conditions (a) $10^{-2} \mathrm{~mol} \mathrm{~L}^{-1}$, (b) $5 \times 10^{-3} \mathrm{~mol} \mathrm{~L}^{-1}$ and (c) $10^{-3} \mathrm{~mol} \mathrm{~L}^{-1}$ and proportion of REE complexed to $\mathrm{HA}$ as a function of $\mathrm{pH}$ for various alkalinity conditions (d) $10^{-2} \mathrm{~mol} \mathrm{~L}^{-1}$, (e) $5 \mathrm{x}$ $10^{-3} \mathrm{~mol} \mathrm{~L}^{-1}$ and (f) $10^{-3} \mathrm{~mol} \mathrm{~L}^{-1}$ (data presented in Appendix A and B).

Fig. 2. (a) Cerium anomaly $\left(\mathrm{Ce} / \mathrm{Ce}^{*}\right)$ as a function of $\mathrm{pH}$, (b) $\mathrm{Ce} / \mathrm{Ce}^{*}$ as a function of carbonate concentrations and (c) $\mathrm{Ce} / \mathrm{Ce} *$ as a function of ionic strength, for variable alkalinity.

Fig. 3. pe-pH diagram for the system Ce-C-O-H at $25^{\circ} \mathrm{C}$ and (a) $I=0.002 \mathrm{~mol} \mathrm{~L}^{-1},[\mathrm{Ce}]=1 \times 10^{-}$ ${ }^{9} \mathrm{~mol} \mathrm{~L}^{-1}, \gamma \mathrm{Ce}=0.66$ and (b) $I=0.008 \mathrm{~mol} \mathrm{~L}^{-1},[\mathrm{Ce}]=2 \times 10^{-8} \mathrm{~mol} \mathrm{~L}^{-1}, \gamma \mathrm{Ce}=0.47$. Solid line correspond to stable relationship ( $\left.\mathrm{Ce}(\mathrm{III})\left(\mathrm{CO}_{3}\right)_{2}{ }^{-} / \mathrm{CeO}_{2}\right)$ and dashed lines to metastable relationships $\left(\mathrm{Ce}(\mathrm{III})\left(\mathrm{CO}_{3}\right)_{2}{ }^{-} / \mathrm{Ce}(\mathrm{IV})\left(\mathrm{CO}_{3}\right)_{5}{ }^{6-}\right)$, while black arrow indicates redox potential evolution of experimental conditions and italic numbers indicate assumed log Q (i.e., 0, 4 or 6). Thermodynamic data are from Doležal and Novák (1959), De Baar et al. (1988) and Möller and Bau (1993).

Fig. 4. Proportion of $\mathrm{La}$ and $\mathrm{Ce}$ bound to $\mathrm{HA}$ (a) as a function of $\mathrm{CO}_{3}{ }^{2-}$ concentrations and (b) as a function of $\mathrm{pH}$ (alkalinity $\left.=10^{-2} \mathrm{~mol} \mathrm{~L}^{-1}\right)$.

Appendix A. Proportion (\%) of Ln species in the ultrafiltrate.

Appendix B. Proportion (\%) of Ln species in the retentate. 

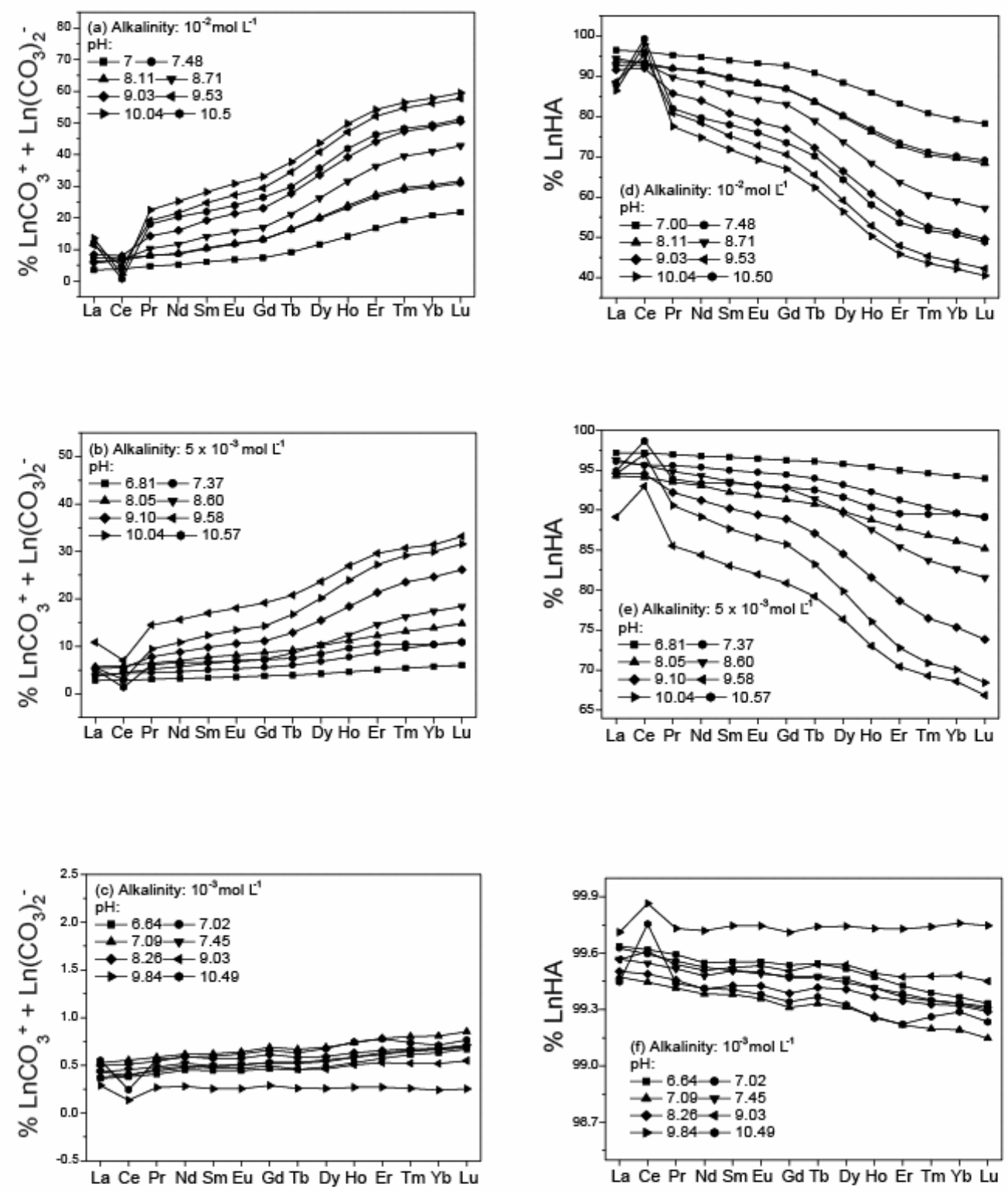

Figure 1. 

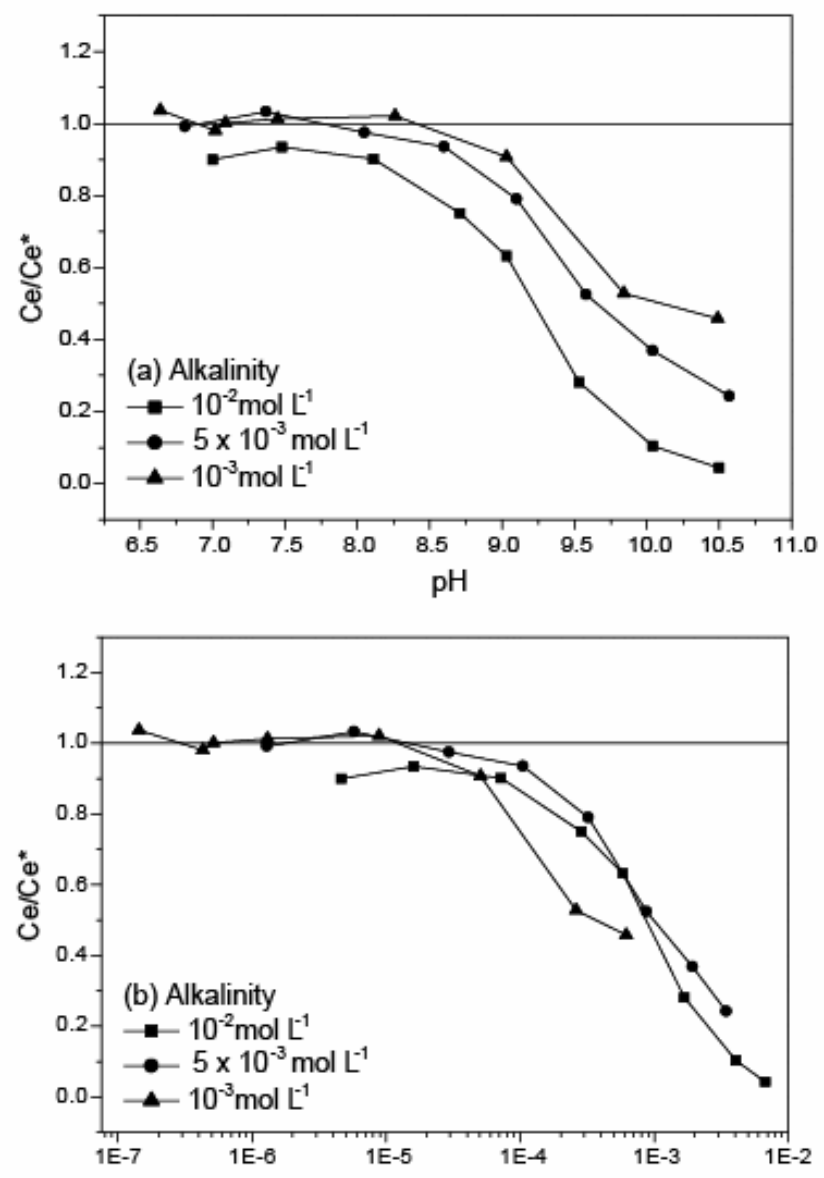

$\left[\mathrm{CO}_{3}^{2}\right]\left(\mathrm{mol} \mathrm{L}^{-1}\right)$

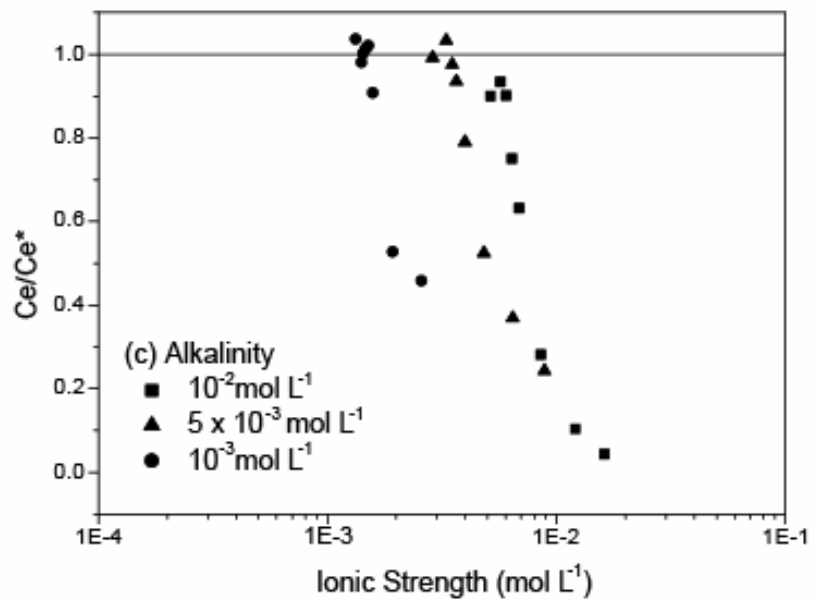

Figure 2. 

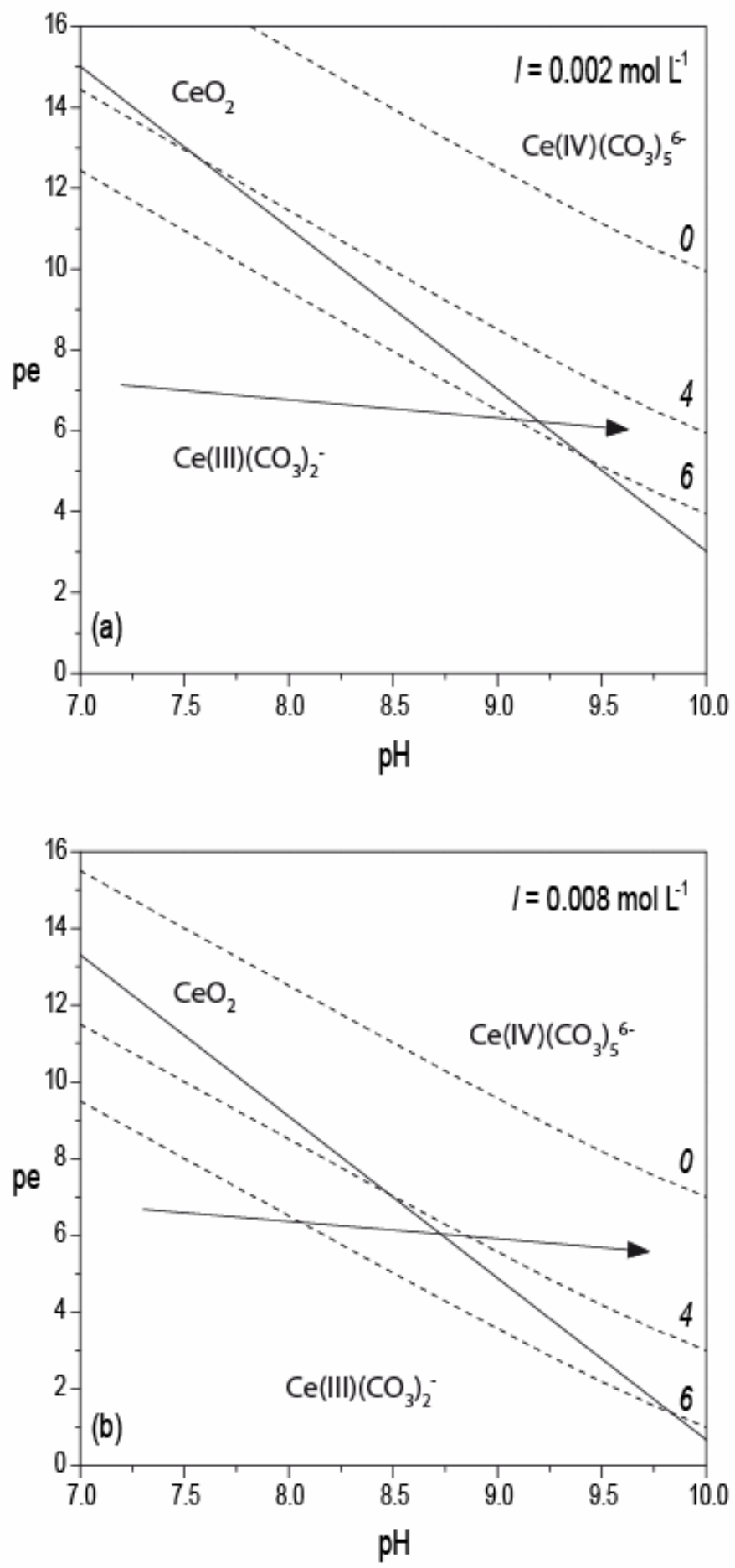

Figure 3. 

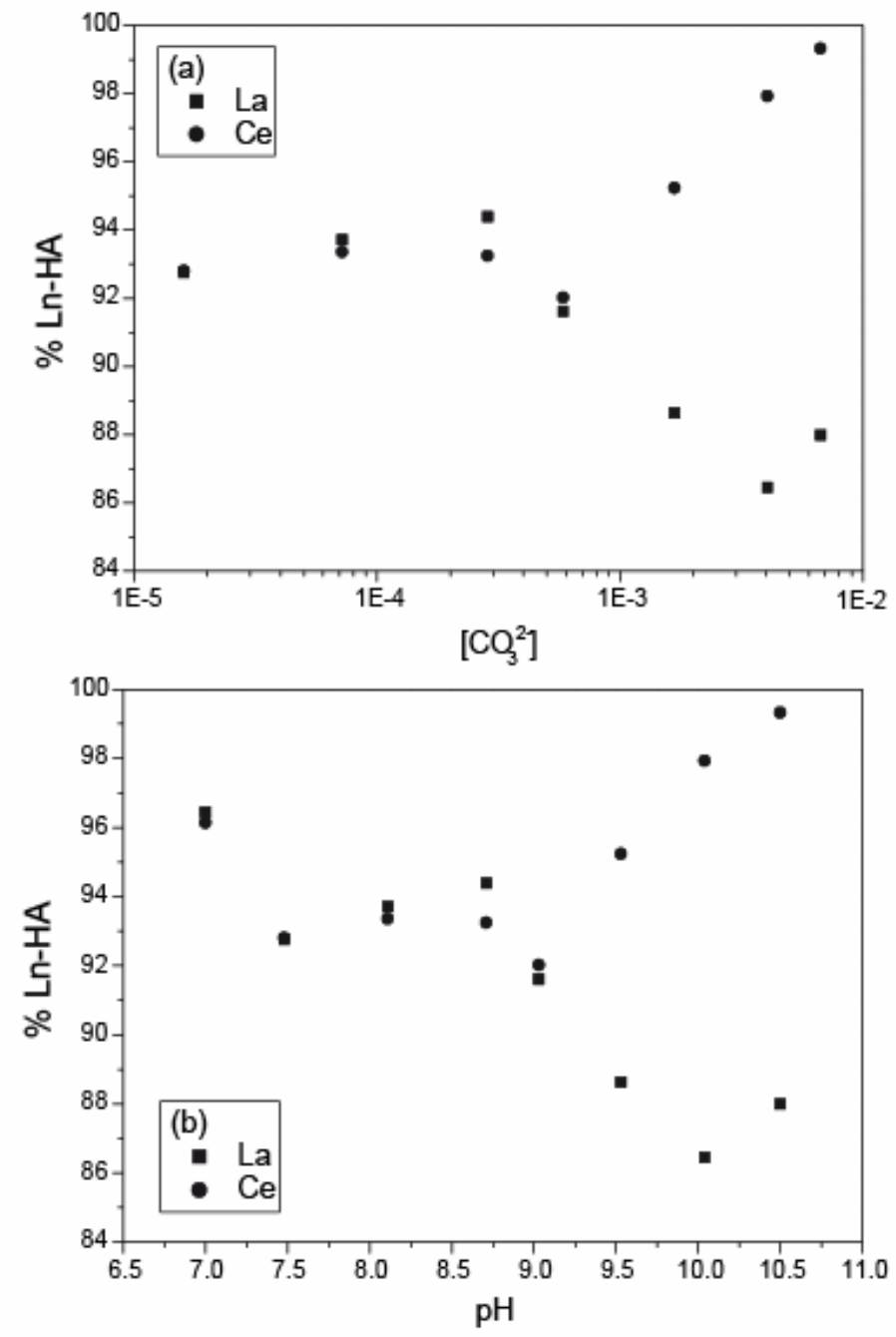

Figure 4. 


\begin{tabular}{ccccccccc} 
Alkalinity: $10^{-3} \mathrm{~mol} \mathrm{~L}^{-1}$ & & & & & & & & \\
$\mathrm{pH}$ & 6.64 & 7.02 & 7.09 & 7.45 & 8.26 & 9.03 & 9.84 & 10.49 \\
\hline $\mathrm{La}$ & 0.36 & 0.37 & 0.53 & 0.43 & 0.50 & 0.43 & 0.29 & 0.55 \\
$\mathrm{Ce}$ & 0.38 & 0.41 & 0.55 & 0.45 & 0.51 & 0.39 & 0.14 & 0.24 \\
$\mathrm{Pr}$ & 0.41 & 0.44 & 0.59 & 0.48 & 0.54 & 0.46 & 0.27 & 0.56 \\
$\mathrm{Nd}$ & 0.45 & 0.47 & 0.62 & 0.52 & 0.59 & 0.49 & 0.28 & 0.59 \\
$\mathrm{Sm}$ & 0.45 & 0.49 & 0.62 & 0.49 & 0.57 & 0.48 & 0.25 & 0.59 \\
$\mathrm{Eu}$ & 0.44 & 0.50 & 0.64 & 0.51 & 0.57 & 0.47 & 0.25 & 0.62 \\
$\mathrm{Gd}$ & 0.46 & 0.53 & 0.69 & 0.52 & 0.61 & 0.50 & 0.29 & 0.66 \\
$\mathrm{~Tb}$ & 0.45 & 0.53 & 0.67 & 0.52 & 0.58 & 0.46 & 0.26 & 0.63 \\
$\mathrm{Dy}$ & 0.48 & 0.56 & 0.69 & 0.54 & 0.59 & 0.46 & 0.26 & 0.67 \\
$\mathrm{Ho}$ & 0.53 & 0.58 & 0.74 & 0.58 & 0.63 & 0.51 & 0.27 & 0.75 \\
$\mathrm{Er}$ & 0.57 & 0.61 & 0.78 & 0.63 & 0.65 & 0.53 & 0.27 & 0.78 \\
$\mathrm{Tm}$ & 0.61 & 0.65 & 0.80 & 0.65 & 0.67 & 0.52 & 0.26 & 0.74 \\
$\mathrm{Yb}$ & 0.63 & 0.67 & 0.81 & 0.67 & 0.68 & 0.52 & 0.24 & 0.71 \\
$\mathrm{Lu}$ & 0.67 & 0.68 & 0.85 & 0.70 & 0.71 & 0.55 & 0.25 & 0.77 \\
\hline
\end{tabular}

Alkalinity: $510^{-3} \mathrm{~mol} \mathrm{~L}^{-1}$

\begin{tabular}{ccccccccc}
$\mathrm{pH}$ & 6.81 & 7.37 & 8.05 & 8.60 & 9.10 & 9.58 & 10.04 & 10.57 \\
\hline $\mathrm{La}$ & 2.83 & 3.92 & 5.71 & 3.68 & 5.41 & 10.86 & 5.46 & 5.08 \\
$\mathrm{Ce}$ & 2.85 & 4.38 & 5.91 & 4.41 & 5.47 & 7.03 & 3.02 & 1.37 \\
$\mathrm{Pr}$ & 3.06 & 4.44 & 6.48 & 5.18 & 7.79 & 14.47 & 9.41 & 6.12 \\
$\mathrm{Nd}$ & 3.25 & 4.64 & 6.94 & 5.70 & 8.77 & 15.62 & 10.83 & 6.64 \\
$\mathrm{Sm}$ & 3.37 & 5.02 & 7.76 & 6.41 & 9.79 & 16.98 & 12.34 & 6.63 \\
$\mathrm{Eu}$ & 3.55 & 5.28 & 8.17 & 6.95 & 10.58 & 18.04 & 13.43 & 6.86 \\
$\mathrm{Gd}$ & 3.77 & 5.58 & 8.70 & 7.25 & 11.11 & 19.14 & 14.27 & 7.18 \\
$\mathrm{~Tb}$ & 3.90 & 6.03 & 9.22 & 8.58 & 12.89 & 20.79 & 16.76 & 7.46 \\
$\mathrm{Dy}$ & 4.24 & 6.82 & 10.16 & 10.33 & 15.46 & 23.64 & 20.12 & 8.39 \\
$\mathrm{Ho}$ & 4.60 & 7.71 & 11.23 & 12.41 & 18.42 & 26.98 & 23.93 & 9.64 \\
$\mathrm{Er}$ & 5.04 & 8.74 & 12.25 & 14.58 & 21.33 & 29.57 & 27.21 & 10.43 \\
$\mathrm{Tm}$ & 5.40 & 9.65 & 13.16 & 16.26 & 23.53 & 30.72 & 29.13 & 10.50 \\
$\mathrm{Yb}$ & 5.75 & 10.36 & 13.87 & 17.37 & 24.64 & 31.41 & 29.94 & 10.40 \\
$\mathrm{Lu}$ & 6.02 & 10.95 & 14.80 & 18.42 & 26.16 & 33.13 & 31.58 & 10.81 \\
\hline
\end{tabular}

Alkalinity: $10^{-2} \mathrm{~mol} \mathrm{~L}^{-1}$

\begin{tabular}{ccccccccc}
$\mathrm{pH}$ & 7.00 & 7.48 & 8.11 & 8.71 & 9.03 & 9.53 & 10.04 & 10.50 \\
\hline $\mathrm{La}$ & 3.55 & 7.25 & 6.29 & 5.61 & 8.39 & 11.37 & 13.56 & 12.01 \\
$\mathrm{Ce}$ & 3.87 & 7.20 & 6.65 & 6.76 & 7.99 & 4.77 & 2.07 & 0.68 \\
$\mathrm{Pr}$ & 4.74 & 8.13 & 8.06 & 10.27 & 14.24 & 19.11 & 22.46 & 18.01 \\
$\mathrm{Nd}$ & 5.23 & 8.57 & 8.81 & 11.73 & 16.04 & 21.55 & 25.25 & 20.34 \\
$\mathrm{Sm}$ & 6.08 & 10.27 & 10.56 & 14.09 & 19.23 & 24.77 & 28.14 & 22.01 \\
$\mathrm{Eu}$ & 6.81 & 11.70 & 11.93 & 15.73 & 21.35 & 27.21 & 30.77 & 23.98 \\
$\mathrm{Gd}$ & 7.34 & 13.07 & 13.18 & 16.96 & 23.06 & 29.44 & 33.03 & 26.51 \\
$\mathrm{~Tb}$ & 9.18 & 16.25 & 16.41 & 21.12 & 27.74 & 34.48 & 37.65 & 29.79 \\
$\mathrm{Dy}$ & 11.61 & 19.75 & 20.09 & 26.25 & 33.56 & 40.85 & 43.65 & 35.67 \\
$\mathrm{Ho}$ & 14.11 & 23.23 & 23.89 & 31.53 & 39.18 & 47.14 & 49.73 & 41.88 \\
$\mathrm{Er}$ & 16.76 & 26.61 & 27.34 & 36.28 & 44.05 & 52.11 & 54.18 & 46.34 \\
$\mathrm{Tm}$ & 19.23 & 28.83 & 29.52 & 39.50 & 47.37 & 54.70 & 56.45 & 48.27 \\
$\mathrm{Yb}$ & 20.79 & 29.81 & 30.43 & 40.93 & 48.65 & 56.20 & 57.85 & 49.38 \\
$\mathrm{Lu}$ & 21.76 & 30.89 & 31.63 & 42.77 & 50.42 & 57.76 & 59.50 & 51.16 \\
\hline
\end{tabular}

Appendix A. Proportion (\%) of Ln species in the ultrafiltrate. 


\begin{tabular}{ccccccccc}
$\begin{array}{c}\text { Alkalinity: } 10^{-3} \mathrm{~mol} \mathrm{~L}^{-1} \\
\mathrm{pH}\end{array}$ & 6.64 & 7.02 & 7.09 & 7.45 & 8.26 & 9.03 & 9.84 & 10.49 \\
\hline $\mathrm{La}$ & 99.64 & 99.63 & 99.47 & 99.57 & 99.50 & 99.57 & 99.71 & 99.45 \\
$\mathrm{Ce}$ & 99.62 & 99.59 & 99.45 & 99.55 & 99.49 & 99.61 & 99.86 & 99.76 \\
$\mathrm{Pr}$ & 99.59 & 99.56 & 99.41 & 99.52 & 99.46 & 99.54 & 99.73 & 99.44 \\
$\mathrm{Nd}$ & 99.55 & 99.53 & 99.38 & 99.48 & 99.41 & 99.51 & 99.72 & 99.41 \\
$\mathrm{Sm}$ & 99.55 & 99.51 & 99.38 & 99.51 & 99.43 & 99.52 & 99.75 & 99.41 \\
$\mathrm{Eu}$ & 99.56 & 99.50 & 99.36 & 99.49 & 99.43 & 99.53 & 99.75 & 99.38 \\
$\mathrm{Gd}$ & 99.54 & 99.47 & 99.31 & 99.48 & 99.39 & 99.50 & 99.71 & 99.34 \\
$\mathrm{~Tb}$ & 99.55 & 99.47 & 99.33 & 99.48 & 99.42 & 99.54 & 99.74 & 99.37 \\
$\mathrm{Dy}$ & 99.52 & 99.44 & 99.31 & 99.46 & 99.41 & 99.54 & 99.74 & 99.33 \\
$\mathrm{Ho}$ & 99.47 & 99.42 & 99.26 & 99.42 & 99.37 & 99.49 & 99.73 & 99.25 \\
$\mathrm{Er}$ & 99.43 & 99.39 & 99.22 & 99.37 & 99.35 & 99.47 & 99.73 & 99.22 \\
$\mathrm{Tm}$ & 99.39 & 99.35 & 99.20 & 99.35 & 99.33 & 99.48 & 99.74 & 99.26 \\
$\mathrm{Yb}$ & 99.37 & 99.33 & 99.19 & 99.33 & 99.32 & 99.48 & 99.76 & 99.29 \\
$\mathrm{Lu}$ & 99.33 & 99.32 & 99.15 & 99.30 & 99.29 & 99.45 & 99.75 & 99.23 \\
\hline
\end{tabular}

Alkalinity: $510^{-3} \mathrm{~mol} \mathrm{~L}^{-1}$

\begin{tabular}{ccccccccc}
$\mathrm{pH}$ & 6.81 & 7.37 & 8.05 & 8.60 & 9.10 & 9.58 & 10.04 & 10.57 \\
\hline $\mathrm{La}$ & 97.17 & 96.08 & 94.29 & 96.32 & 94.59 & 89.14 & 94.54 & 94.92 \\
$\mathrm{Ce}$ & 97.15 & 95.62 & 94.09 & 95.59 & 94.53 & 92.97 & 96.98 & 98.63 \\
$\mathrm{Pr}$ & 96.94 & 95.56 & 93.52 & 94.82 & 92.21 & 85.53 & 90.59 & 93.88 \\
$\mathrm{Nd}$ & 96.75 & 95.36 & 93.06 & 94.30 & 91.23 & 84.38 & 89.17 & 93.36 \\
$\mathrm{Sm}$ & 96.63 & 94.98 & 92.24 & 93.59 & 90.21 & 83.02 & 87.66 & 93.37 \\
$\mathrm{Eu}$ & 96.45 & 94.72 & 91.83 & 93.05 & 89.42 & 81.96 & 86.57 & 93.14 \\
$\mathrm{Gd}$ & 96.23 & 94.42 & 91.30 & 92.75 & 88.89 & 80.86 & 85.73 & 92.82 \\
$\mathrm{~Tb}$ & 96.10 & 93.97 & 90.78 & 91.42 & 87.11 & 79.21 & 83.24 & 92.54 \\
$\mathrm{Dy}$ & 95.76 & 93.18 & 89.84 & 89.67 & 84.54 & 76.36 & 79.88 & 91.61 \\
$\mathrm{Ho}$ & 95.40 & 92.29 & 88.77 & 87.59 & 81.58 & 73.02 & 76.07 & 90.36 \\
$\mathrm{Er}$ & 94.96 & 91.26 & 87.75 & 85.42 & 78.67 & 70.43 & 72.79 & 89.57 \\
$\mathrm{Tm}$ & 94.60 & 90.35 & 86.84 & 83.74 & 76.47 & 69.28 & 70.87 & 89.50 \\
$\mathrm{Yb}$ & 94.25 & 89.64 & 86.13 & 82.63 & 75.36 & 68.59 & 70.06 & 89.60 \\
$\mathrm{Lu}$ & 93.98 & 89.05 & 85.20 & 81.58 & 73.84 & 66.87 & 68.42 & 89.19 \\
\hline
\end{tabular}

\begin{tabular}{ccccccccc}
$\begin{array}{c}\text { Alkalinity: } 10^{-2} \mathrm{~mol} \mathrm{~L}^{-1} \\
\mathrm{pH}\end{array}$ & 7.00 & 7.48 & 8.11 & 8.71 & 9.03 & 9.53 & 10.04 & 10.50 \\
\hline $\mathrm{La}$ & 96.45 & 92.75 & 93.71 & 94.39 & 91.61 & 88.63 & 86.44 & 87.99 \\
$\mathrm{Ce}$ & 96.13 & 92.80 & 93.35 & 93.24 & 92.01 & 95.23 & 97.93 & 99.32 \\
$\mathrm{Pr}$ & 95.26 & 91.87 & 91.94 & 89.73 & 85.76 & 80.89 & 77.54 & 81.99 \\
$\mathrm{Nd}$ & 94.77 & 91.43 & 91.19 & 88.27 & 83.96 & 78.45 & 74.75 & 79.66 \\
$\mathrm{Sm}$ & 93.92 & 89.73 & 89.44 & 85.91 & 80.77 & 75.23 & 71.86 & 77.99 \\
$\mathrm{Eu}$ & 93.19 & 88.30 & 88.07 & 84.27 & 78.65 & 72.79 & 69.23 & 76.02 \\
$\mathrm{Gd}$ & 92.66 & 86.93 & 86.82 & 83.04 & 76.94 & 70.56 & 66.97 & 73.49 \\
$\mathrm{~Tb}$ & 90.82 & 83.75 & 83.59 & 78.88 & 72.26 & 65.52 & 62.35 & 70.21 \\
$\mathrm{Dy}$ & 88.39 & 80.25 & 79.91 & 73.75 & 66.44 & 59.15 & 56.35 & 64.33 \\
$\mathrm{Ho}$ & 85.89 & 76.77 & 76.11 & 68.47 & 60.82 & 52.86 & 50.27 & 58.12 \\
$\mathrm{Er}$ & 83.24 & 73.39 & 72.66 & 63.72 & 55.95 & 47.89 & 45.82 & 53.66 \\
$\mathrm{Tm}$ & 80.77 & 71.17 & 70.48 & 60.50 & 52.63 & 45.30 & 43.55 & 51.73 \\
$\mathrm{Yb}$ & 79.21 & 70.19 & 69.57 & 59.07 & 51.35 & 43.80 & 42.15 & 50.62 \\
$\mathrm{Lu}$ & 78.24 & 69.11 & 68.37 & 57.23 & 49.58 & 42.24 & 40.50 & 48.84 \\
\hline
\end{tabular}

Appendix B. Proportion (\%) of Ln species in the retentate. 